\title{
Blodbanken i Oslo 22. juli 2011
}

\author{
Vi trodde vi hørte et kraftig lynnedslag. Vi var på jobb ved Blodbanken ved Oslo universitetssykehus om \\ ettermiddagen en grå sommerdag. Men det var ikke noe lynnedslag. «Gul alarm» ble raskt oppgradert \\ til «rød alarm».
}

TR

Engelsk oversettelse av hele artikkelen på www.tidsskriftet.no

Blodbanken i Oslo er landets største og skal ha et lager på minimum 80 erytrocyttkonsentrater (SAG) for blodtype O RhD negativ. Etter en del blodbestillinger like i forkant av eksplosjonen falt beholdningen av $\mathrm{O}$ RhD-negativt blod under denne grensen, slik at vi kun hadde 55 poser SAGblod. Blodlageret ellers, av andre blodtyper, var optimalt. O RhD-negativt SAG kan brukes som kriseblod/beredskapsblod der pasientens blodtype er ukjent, fordi det kan gis til pasienter med alle blodtyper, forutsatt at de ikke har irregulære blodtypeantistoffer. Siden kun $15 \%$ av Norges befolkning har egenskapen RhD-negativitet (1), er blodtype $\mathrm{O} \mathrm{RhD}$ negativ en begrenset og svært verdifull ressurs.

Jeg ble katastrofeleder i avdelingen fordi jeg var vakthavende overlege og ledet arbeidet $i$ tett dialog med daglig leder og vakthavende assistentlege. Blodbanken i Oslo består av tre seksjoner - for henholdsvis blodgivning, komponentfremstilling og immunhematologi. Under katastrofen ble alle seksjonene godt bemannet med rundt 28 ansatte, som gjorde en formidabel innsats. Ved Seksjon for immunhematologi var personell fra dagvakten til stede da den første katastrofemeldingen kom. Av disse ble sju bioingeniører igjen, og sammen med kveldsvaktene hadde vi da ti medarbeidere frem til midnatt. De andre seksjonene stilte opp med henholdsvis 12 og tre bioingeniører/sykepleiere både 22. og 23. juli.

Kort tid etter den høyeste beredskapsalarmen var utløst, fikk vi den første traumepakkebestillingen fra Akuttmottaket. Traumepakken, som består av fem enheter SAG, fem enheter Octaplas og to enheter trombocyttkonsentrat, utleveres omgående i akutte tilfeller. Det gjøres uten at nødvendig enkel forlikelighetstest og/eller utvidet forlikelighetstest mellom pasient og blodgiver (og uten eventuelle immunhematologiske utredninger) er utført der transfusjon er indisert som en del av livreddende behandling. Siden pasientenes blodtype ikke var kjent på bestillingstidspunktet, ble vi nødt til å bruke O RhD-negativt kriseblod. Mer O RhD-negativt blod ble levert ut i løpet av kort tid til skadede fra Oslo sentrum og etter hvert fra Utøya. Dette utgjorde en betydelig del av vårt beredskapslager av O RhD-negativt blod. Vi kontaktet tidlig andre blodbanker i Sør-Norge for å få oversikt over hvor mye blod vi eventuelt kunne kjøpe fra dem. Da omfanget av katastrofen viste seg å være ubegripelig stort, vurdert ut fra medieinformasjonen, kjøpte vi 80 enheter O RhDSAG-blod, som ankom avdelingen i løpet av kvelden. Samarbeidet med de andre blodbankene fungerte meget godt.

\section{Blodgiverne}

Parallelt med innkjøp fra andre blodbanker besluttet vi å kalle inn $\mathrm{O} \mathrm{RhD}$-negative blodgivere, siden beholdningen av denne blodtypen i utgangspunktet var lav. I vanlig rutine er tapping av blodgivere en dagoppgave, med døgnbasert hjemmevakt for en sykepleier/bioingeniør i tillegg til vakthavende assistentlege. Ikke før hadde tappepersonellet ringt et par givere, ankom den forste blodgiveren uanmeldt. Vedkommende var i Oslo sentrum da bomben eksploderte og følte et sterkt behov for å gjøre

\section{«Det var imponerende og overveldende å oppleve responsen fra hundrevis av blodgivere»}

noe for de skadede. Han gikk hele veien fra sentrum til Ullevål, ettersom all offentlig transport sto.

I timene som fulgte kom det mange hundre blodgivere som ønsket å gi blod ja hele busslaster. Det var trafikkaos utenfor Laboratoriebygget på Ullevål, der Blodbanken holder til - trafikken sto helt opp på Ringveien. Politiet måtte dirigere trafikken, da køen var til hinder for ambulanser og andre utrykningskjøretøyer. Det var blodgivere overalt $-\mathrm{i}$ vandrehallen, trappene, heisene, $i$ tappelokalene. Ved inngangen prøvde vi å sile ut blodgivere med blodtype O RhD negativ som tidligere hadde gitt blod ved Ullevål, for i øyeblikkelig hjelp-situasjoner kan man kun benytte blod fra givere som er registrert ved den aktuelle blodbanken. Dette nyttet ikke - folk strømmet på. Vektere fra Sikkerhetsavdelingen fikk etter hvert kontroll over situasjonen.

12 medarbeidere fra Seksjon for blodgivning tok imot 63 blodgivere og besvarte nærmere 500 telefoner frem til midnatt, men mange forble ubesvart. Tre ansatte fra Seksjon for komponentfremstilling håndterte alle de tappede blodenhetene. Mikrobiologisk avdeling utførte de infeksjonsserologiske analysene som øyeblikkelig hjelp og sendte oss svarene elektronisk. Dette er rutine på dagtid, men som følge av omorganiseringsprosessen ved Oslo universitetssykehus gjøres all øyeblikkelig hjelp-testing etter kl 1430 ved Rikshospitalet og serologisvar fakses over. Dette innebærer en potensiell risiko for forsinkelser og feil.

Ved midnatt la vi inn en melding på Blodbankens nettside, der vi takket alle blodgiverne som hadde stilt opp. På Facebook la vi ut en melding om at vi skulle ha tapping lørdag 23. juli. Den dagen ble 160 blodgivere tappet, de fleste med blodtype $\mathrm{O} \mathrm{RhD}$ negativ. Vi valgte å la være å produsere trombocyttkonsentrat fra de ekstra tappede enhetene, fordi det så ut til at behovet ikke var større enn det vi kunne dekke med det vi allerede hadde på lager.

\section{Blodforbruket}

Forbruket av blodkomponenter i løpet av 22. og 23. juli ble 60 erytrocyttkonsentrater, 14 trombocyttkonsentrater og 51 Octaplas. Totalt forbruk i løpet av de første fem dagene ble henholdsvis 86,14 og 61 enheter for de til sammen 32 innlagte skadede på Ullevål (personlig meddelelse Berit Gran, Avdeling for immunologi og transfusjonsmedisin, Oslo universitetssykehus, Ullevål). Ikke alle trengte transfusjon. Ved andre sykehus som tok imot enda flere pasienter, dog med mindre alvorlige skader, var blodforbruket minimalt. Etter at alle pasientprøvene ble typet ut, gikk vi over til utlevering av blodtypelikt blod. Det relativt lave blodforbruket er i tråd med det som er rapportert fra andre katastrofer (2-4).

\section{Ekstern kommunikasjon}

På kvelden 22. juli ble vi overrasket av en oppfordring på fjernsynet om at alle som ønsket å gi blod, kunne møte opp på Blodbanken. En slik oppfordring kom ikke fra sykehuset. Kommunikasjonsstaben ved Oslo universitetssykehus registrerte en intens aktivitet på Twitter om at mange ønsket å gi blod, og presenterte spørsmålet for katastrofeledelsen (personlig meddelelse, kommunikasjonsrådgiver Anders Bayer, kommunikasjonsstaben, Oslo uni- 
versitetssykehus) og Blodbanken. I samarbeid med kommunikasjonsstaben gikk vi derfor ut med melding på Twitter om at vi trengte Ullevåls etablerte $\mathrm{O} \mathrm{RhD}$-negative givere. Meldingen ble sendt videre over 100 ganger og fanget opp av mediene. Den første meldingen måtte presiseres ytterligere med flere nye Twitter-meldinger om at kun sykehusets etablerte blodgivere måtte melde seg, ettersom pågangen ble så enorm.

Kommunikasjonsstaben hadde også kontakt med flere medier i løpet av kvelden for å nyansere og presisere budskapet. De var også nøye med å be medier, vektere og politi takke alle som møtte opp, men som måtte avvises, for engasjementet (personlig meddelelse, Anders Bayer). Etter melding fra oss sendte kommunikasjonsstaben ut en ny Twitter-melding litt før midnatt om at behovet var dekket og takket alle som hadde stilt opp.

\section{Tidligere katastrofer}

Erfaringer fra tidligere katastrofer i andre land viser en generell tendens til lite blodforbruk i forhold til katastrofeomfanget (2-4). Etter terrorangrepene i USA 11. september 2001 var det nærmere 3000 døde og 4000 skadede. Likevel ble kun 200 personer innlagt på sykehus, og blodforbruket første døgn var totalt kun 258 erytrocyttenheter (2). Dette skyldes blant annet at de fleste pasientene hadde inhalasjons- og brannskader, som ikke nødvendigvis er blodkrevende. Likevel ble en kolossal tappeprosess satt i gang, noe som resulterte i nesten 600000 blodgivertappinger $(2,3)$. Food and Drug Administration (FDA) åpnet for transfusjon av blodkomponenter som ikke var fullstendig infeksjonstestet og bruk av frivillige i infeksjonstestingen.

Det viste seg at ingen torde transfundere blod som ikke var fullstendig testet. Flere andre enheter måtte kasseres grunnet feil ved testingen. Dette viser hvor viktig det er ikke å gi dispensasjon fra viktige sikkerhetskrav ved katastrofer. Mange sykehus klarte heller ikke å infeksjonsteste så mange tappede enheter. Til slutt måtte minst 300 000 enheter kasseres - enorme ressurser var brukt forgjeves $(2,3)$.

\section{Symboleffekt og altruisme}

Under den annen verdenskrig var blodgivning et solidaritetssymbol - de som var «hjemme», kunne vise sin støtte til soldatene $\mathrm{i}$ felten. Ved senere katastrofer har det vært flere eksempler på overveldende iver fra blodgivere og andre som har ønsket å gi blod (2-6).

Det er både forståelig og naturlig at man ønsker å gjøre noe for sine medmennesker når en katastrofe inntreffer. Altruisme er hovedmotivasjonen for mange blodgivere (7). Selv om altruisme også er grunnen til at blodgivere fortsetter sin blodgiverkarriere (7), er rekruttering av givere utenom katastrofer og det å få dem til å komme tilbake flere ganger en stor utfordring for alle blodbanker.

\section{Utfordringer}

En av de største utfordringene tidlig på kvelden 22. juli var at vi måtte estimere behovet for blodforbruk uten å vite katastrofeomfanget og uten å få noen offisiell informasjon. Vi var nødt til å dekke behovet, men unngå å overdimensjonere tapping av blodgivere. Noen av de skadede skulle mest sannsynlig reopereres i løpet av kort tid, noen til og med flere ganger, eller de kunne ha et transfusjonsbehov over lengre tid. Vi kunne ikke tappe alle som møtte opp. Vi kunne heller ikke tømme reservene til de andre blodbankene. Vi var nødt til å finne den riktige balansen - tappe og kjøpe tilstrekkelig mange blodenheter og holde dette innen rimelige grenser. Men hva var rimelig? Overdreven tapping og kjøp av blod fra andre blodbanker kunne føre til massiv kassasjon av ikke-brukte enheter, sløsing med penger/ ressurser, skade blodgiverrekrutteringen senere og skade tilliten til transfusjonstjenesten. Etter flere overveielser tappet vi til midnatt 22. juli og bestemte oss for å holde åpent hele dagen 23. juli. Dermed tappet vi totalt 220 givere. Det viste seg i etterkant at kassasjonsprosenten ble svært lav.

Det var imponerende og overveldende å oppleve responsen fra hundrevis av blodgivere. Derimot ble håndtering av alle dem som møtte opp og ønsket å gi blod, svært vanskelig. Her har vi et forbedringspotensial. Fabelaktig og snar innsats fra Sikkerhetsavdelingen og politiet bidro til å løse kaoset. I ettertid ser vi at et helt klart budskap til mediene og andre kommunikasjonsplattformer på et mye tidligere tidspunkt hadde vært på sin plass. Takket være en formidabel innsats fra alle medarbei- derne som stilte opp i løpet av svært kort tid, fungerte beredskapen ved Blodbanken i Oslo bra.

Ved en katastrofe av dette omfang kan kun allerede tappede og klarerte enheter i blodbankens lager benyttes til akutt livreddende behandling. Fra tidspunktet der blodgiveren møter opp til enheten er klar til transfusjon går det flere timer. Derfor er blodbankene avhengige av jevn tilgang på blodgivere for å kunne opprettholde et tilstrekkelig blodlager til enhver tid. Blodkomponenter har begrenset holdbarhet. Derfor vil ikke impulsiv og overdreven tapping av blodgivere i løpet av kort tid sikre pasientenes transfusjonsbehov.

\section{Cigdem Akalin Akkök}

uxciak@ous-hf.no

Avdeling for immunologi og transfusjonsmedisin Oslo universitetssykehus, Ullevål

Cigdem Akalin Akkök (f. 1960) er spesialist i immunologi og transfusjonsmedisin, ph.d. og seksjonsoverlege ved Avdeling for immunologi og transfusjonsmedisin, Oslo universitetssykehus, Ullevål.

Ingen oppgitte interessekonflikter.

\section{Litteratur}

1. Heier HE, Kornstad L. Blodtypeserologi. I: Fagerhol MK, Solheim BG, red. Immunologi og transfu sjonsmedisin. Oslo: Universitetsforlaget, 1995: $166-214$

2. Schmidt PJ. Blood and disaster - supply and demand. N Engl J Med 2002; 346: 617-20.

3. Hess JR, Thomas MJ. Blood use in war and disaster: lessons from the past century. Transfusion 2003: 43: 1622-33.

4. Abolghasemi H, Radfar MH, Tabatabaee M et al. Revisiting blood transfusion preparedness: experience from the Bam earthquake response. Prehosp Disaster Med 2008; 23: 391-4.

5. Moorgate tube train disaster. Part 1. Response of medical services. BMJ 1975; 3: 727-9.

6. Kuruppu KK. Management of blood system in disasters. Biologicals 2010; 38: 87-90.

7. Sojka BN, Sojka P. The blood donation experience: self-reported motives and obstacles for donating blood. Vox Sang 2008; 94: 56-63.

Mottatt 21.10. 2011 og godkjent 10.11. 2011

Medisinsk redaktør Petter Gjersvik. 